\title{
ОБМЕЖЕННЯ ЗДІЙСНЕННЯ ПРАВА НА НАЛЕЖНЕ БАТЬКІВСЬКЕ ВИХОВАННЯ МАЛОЛІТНІХ ОСІБ: СУТНІСТЬ І КРИТЕРІЇ
}

Виключне значення для кожної дитини має право на належне батьківське виховання як умова нормального становлення особистості. Відповідне право належить кожній дитині від народження, має відносний характер у здійсненні та захисті, оскільки законом чітко визначено зобов'язаних осіб у відповідних правовідносинах - батьків. Належне виховання для особи з раннього дитинства до підліткового віку $є$ визначальним, оскільки саме у цей період за природними показниками людина не здатна задовольнити більшість своїх потреб, адекватно усвідомлювати їх значення та належні умови для їх задоволення, потребує попередження від виникнення депривації як наслідку незадовільних психологічних, емоційних відносин на зазначених етапах розвитку особистості тощо.

Психічні якості дитини зумовлюють певні правові обмеження у здійсненні прав, які слід відрізняти від соціально-економічних, фізичних, вікових тощо, що залежать від відповідних умов, які у певних випадках можуть бути враховані при правовому регулюванні відносин для забезпечення певного інтересу особи залежно від його значущості, але можуть і не впливати на правовий механізм. Зокрема, психічні, вікові, розумові та фізіологічні можливості малолітньої особи повинні бути враховані при правовому врегулюванні сімейних відносин, зокрема, й відносин із батьківського виховання, впли- ваючи на встановлення певних правових обмежень.

У ст. 22 Конституції України встановлено, що при прийнятті нових законів, внесенні змін до чинних не допускається звуження змісту та обсягу прав і свобод. У цьому положенні йдеться про конституційні права, оскільки не можливо не встановлювати іншого змісту та обсягу суб'єктивних прав взагалі [1, с. 65]. Обмеження особистих немайнових прав фізичної особи відповідно до ст. 274 ЦК України, встановлених Конституцією України, можливе лише у випадках, передбачених нею. Обмеження особистих немайнових прав фізичної особи, встановлених іншим законом, можливе лише у випадках, передбачених ними.

Обмеження суб'єктивних прав у юриспруденціі має декілька значень: повне обмеження деяких суб'єктивних прав у зв'язку 3 певними надзвичайними обставинами, встановленими законом; обмеження здійснення права як спосіб впливу на поведінку суб'єктів права через зменшення варіантів дозволеної поведінки (в межах суб'єктивного права) шляхом встановлення часових, просторових, суб'єктивних умов.

Зважаючи на оціночний характер належності виховання, складність визначення меж правомірної поведінки батьків відносно виховання загалом, необхідним $€$ узагальнення обмежень здійснення й права на належне виховання й прав дитини 
і батьків, які сприяють чи створюють умови або перешкоди для реалізації такого права.

Обмеження здійснення суб'єктивних цивільних прав досліджувалися О.Є Мічуріним, М.О. Стефанчуком, О.О. Котом, З.В. Ромовською, А.Й. Пергамент, О.М. Нечаєвою, Є.М. Ворожейкіним, В.О. Рясенцевим, Л.А. Ольховик, Н.М. Опольською, О.В. Мельник, Г.О. Резнік та іншими вченими, які присвячували свої роботи особистим немайновим правам дітей.

Аналіз обмежень окремих немайнових прав дітей здійснювався О.В. Синєгубовим, Л.В. Красицькою, В.О. Кожевніковою, але залишається відкритим питання визначення сутності та особливостей обмеження здійснення права на належне батьківське виховання.

Метою статті є визначення сутності обмежень здійснення права на належне батьківське виховання малолітніх осіб і критеріїв таких обмежень, оскільки відповідне право опосередковує значну кількість важливих потреб дитини на важливому етапі становлення їі особистості.

Основною умовою застосування правових обмежень здійснення особистих немайнових прав дитиною $€$ неможливість реалізації конкретного суб'єктивного права частково або повністю чи тимчасово $[1$, с. 77 ; 2, с. 193-194]. Обмеження у здійсненні права є умовами, що передують певній поведінці в межах права, або юридичними фактами, які передбачені гіпотезою норми права та визначають виникнення й порядок здійснення суб'єктивного права взагалі або окремої його правомочності.

Отже, обмеженнями є умови, які необхідні для здійснення права та створюють ускладнення для його реалізаціі [3, с. 213, 215]. Вплив таких обмежень для дитини полягає у відсутності можливості автономного вчинення певних дій до досягнення 14-річного віку, оскільки є об'єктивно не можливим чи ускладненим само- стійним набуттям певних благ, які зумовлені найкращими інтересами дитини. Такі обмеження при правореалізації покладені на особу з метою охорони іï ж інтересів та прав батьків, надмірне втручання в них $є$ недопустимим у демократичному суспільстві. Але розсуд, залишений батькам у правореалізації з метою відсутності необірунтованого втручання у права, створює ризики саме для виховання дитини, що буде мати ознаки належного.

Здійснення права на належне батьківське виховання зумовлюється й реалізацією спеціальних правомочностей, пов'язаних із педагогічним і психологічним впливом на дитину, й забезпеченням інших особистих немайнових прав дитини, які створюють відповідні умови для задоволення дефіцитарих потреб з фізичного розвитку та піклування, морального, інтелектуального розвитку дитини, розвитку іï здібностей, розширення світогляду, що характеризує мета-потреби особистості.

Задоволення всіх інтересів дитини $€$ можливим шляхом комплексного забезпеченні іi прав батьками, на яких і покладено відповідні обов'язки. Тому, говорячи про обмеження як про умови, в яких відбувається правореалізація, окрім безпосередніх можливостей отримання виховання через спеціальні способи та прийоми, необхідно враховувати ті обставини, які створюються під час здійснення інших прав і свобод дитини або батьківських прав. Зокрема, це стосується свободи пересування. Малолітня особа має право на виїзд за межі України лише за згодою батьків або в іхньому супроводі чи в супроводі осіб, які ними уповноважені.

Обмеження у здійсненні права на свободу пересування встановлено 3 метою охорони інтересів дитини та повинно здійснюватися в іï найкращих інтересах. Право надання дозволу на виїзд дитини за кордон батьками передбачено для оцінки 
сприяння виїзду іï інтересам та для охорони батьківських прав, оскільки переїзд (тимчасовий виїзд) тягне за собою зміну порядку спілкування дитини з батьками, порядку участі у вихованні, зміну звичного середовища дитини, що впливає на ii подальше життя та виховання. Отже, реалізація можливості дитини на виїзд за кордон має обмеження у здійсненні, що по суті залежить від розсуду батьків і має ризики необгрунтованого обмеження.

Незгода батьків на виїзд дитини за кордон може бути виявом принципової позиції, наслідком конфлікту між батьками, які проживають окремо та не можуть знайти спільну мову, що в певних випадках може мати й ознаки зловживанням батьківськими правами [4; 5, с. 125].

Л.В. Красицька не визнає такі випадки зловживанням, оскільки надання дозволу на виїзд дитини за межі України є здійсненням права на вибір місця проживання та свободу пересування [6, с. 219]. B.I. Труба вважає, що зловмисне ненадання такого дозволу має визнаватися невиконання батьками своїх обов'язків із виховання [7, с. 52]. Зважаючи на необхідність врахування інтересів дитини при реалізації зазначеного права, у судовій практиці таку незгоду справедливо визнають зловживанням батьківським правом [8; 9].

Місце проживання дитини до десяти років визначається батьками за їх згодою, дитини, яка досягла десяти років, - за спільною згодою батьків і самої дитини (ч. 2 ст. $160 \mathrm{CK}$ України). Так, законом встановлено правові обмеження для здійснення права дитини на вільний вибір місця проживання та права на свободу пересування [2, с. 189]. Якщо мати та батько, які проживають окремо, не дійшли згоди про те, з ким із них буде проживати малолітня дитина, спір між ними може бути вирішений органом опіки та піклування або судом (ст. 161 СК України). В цьому кон- тексті доцільним є надання можливості дитині з 10-річного віку порушувати питання перед компетентними органами про місце іï проживання у випадку відсутності згоди між батьками. Відповідний засіб буде важливим в рамках захисту прав дитини у випадках зловживання батьками відповідними правами для зведення особистих рахунків між собою.

$\mathrm{У}$ разі встановлення роздільного проживання малолітньої дитини з одним із батьків відбувається встановлене відповідно до закону обмеження здійснення права на належне виховання. Батькам надано право укласти в письмовї формі договір про права та обов'язки того з батьків, який проживає окремо. Якщо з приводу цього виникає спір, він вирішується у встановленому законом порядку. При обмеженні у такому випадку здійснення права батька чи матері на безперешкодне спілкування, виховання своєї дитини права того 3 батьків, 3 яким проживає дитина, розширюються [5, с. 163].

Принцип рівності батьків у вихованні може бути обмеженим в інтересах дитини, а право на отримання виховання від іншого з батьків для дитини не обмежується. У таких випадках належність гендерного виховання, особистий приклад батьків із налагодження відносин відбувається ускладнено, але розвиток дитини у стійкому середовищі має бути забезпеченим.

Отримання належного виховання малолітньою особою залежить від відповідних методів, які законом не визначені. Закон надав батькам право ї обирати за виключенням тих, які суперечать закону, моральним засадам суспільства (ч. 3 ст. 151 СК України). При дотриманні відповідних меж презюмується, що виховання здійснюється належно. Однак можна поставити під сумнів пропорційність встановленого обмеження права на отримання виховання дійсно «належними» методами за таких широких меж. 
Відповідно до позиції Комітету Міністрів Ради Європи всі, хто бере участь у вихованні малолітніх осіб, повинні мати можливість використовувати досягнення сучасних досліджень і знання про Концепцію раннього виховання, брати участь у таких дослідженнях [10]. Позитивне виховання дітей грунтується на поведінці батьків, заснованій на найвищих інтересах дитини щодо виховання, розвитку здібностей, а також дотриманні рамок, в яких дитина може повноцінно розвиватися [11].

Закріплення методів виховання чинним законодавством здійснено опосередковано через встановлення заборон, пряме та явне порушення яких може запустити механізм державного контролю. Важливою $€$ та обставина, що зміст позитивного виховання (або належного за CK України) суттєво відрізняється від змісту виховання взагалі, оскільки останне, як вплив на особистість, може бути таким, що призводить до психологічних травм, засвоєння правил поведінки та навичок, які суперечать загальноприйнятим соціальним нормам, негативної соціалізації.

Незважаючи на загальновизнаний виховний потенціал авторитетного (демократичного) стилю у вихованні дітей [12, с. $111-115 ; 13$, с. 18], законодавством не встановлено для батьків відповідних моделей виховного впливу. Тому застосовування батьками різних методів виховання повинні бути поряд 3 іншими його аспектами грунтовно дослідженими при вирішенні відповідними органами питання про порушення прав малолітніх осіб 3 метою встановлення наявності чи відсутності негативного впливу на психологічні та психічні якості дитини, розвиток тощо.

Відповідні положення мають особливе значення при вирішенні судами справ, у яких досліджуються обставини виховання, під час використання результатів психологічних досліджень, у результаті яких можливо оцінити вплив на дитину. Методи виховання, які використовуються батьками, можуть бути важливим критерієм для визначення місця проживання дитини, визначення способів участі у вихованні того з батьків, який проживає окремо, а їх зміна - при поверненні дитини батькам, поновленні батьківських прав, затвердженні плану соціального супроводу сім’і дитини тощо. Їх самостійне значення в рамках підстав позбавлення батьківських прав складно визнати, якщо не порушено встановлених законом меж. Тому й зловживання батьками правом на обрання методів виховання за відсутності реальної загрози порушення прав дитини й ухилення від обов'язків з виховання не може однозначно тягнути за собою позбавлення батьківських прав, для чого необхідна винна поведінка батьків, системність або відібрання дитини, якщо відсутні ті ж підстави або якщо залишення дитини у них визнано безпечним для ї̈ життя, здоров'я та морального виховання.

Американським професійним товариством 3 питань зловживань щодо дітей було узагальнено поведінку батьків як психологічне насильство відносно дитини, що може виявлятися у відторгненні (вербальні та невербальні акти демонстрації байдужого ставлення); у тероризуванні (реальна загроза чи можливість завдання фізичної шкоди дитині, покидання дитини напризволяще, знищення особистих речей дитини); в ізоляції дитини (відмова у задоволенні потреб у спілкуванні з іншими особами); в експлуатації, емоційній депривації, недбалому ставленні до здоров'я та освіти.

Психологічне насильство над дитиною може бути неодноразовою поведінкою одного з батьків або екстремальною обставиною, коли дитині дають зрозуміти іï нікчемність, що іi ніхто не любить, вона є небажаною тощо [14, с. 30-33, 209-233]. Зазначені вияви здебільшого є латентними. 
Як справедливо наголошує В.П. Мироненко, мета, завдання та методи виховання дітей не повинні сприйматися батьками лише 3 позиціï спеціальних форм педагогічного впливу. Головним $€$ розуміння батьками неправильних напрямів виховання, коли батьківське піклування та виховання дітей стає абстрактною декларацією [15, с. 101]: вияв надмірної суворості, невимогливості до дітей, перекладення виховних функцій на інші соціальні інститути, відсторонення дітей від життя сім’і, невміння адекватно використовувати прийоми заохочення та покарання, надмірне задоволення дитячих забаганок [16, с. 60].

Батькам національним законодавством наданий широкий розсуд щодо питань виховання, який відповідає міжнародним стандартам щодо пропорційності втручання у право. Коли національна система державного контролю не діє належними чином, залучається у крайніх випадках, не розрахована на реальні превентивні заходи, процес виховання та вплив його обставин на долю дитини $€$ майже незворотним.

Відносно здійснення права батьків на визначення форм виховання також можна зазначити про певні обмеження здійснення права дитини на батьківське виховання, встановлені законом. При залученні до виховання інших осіб (мачухи, вітчима, діда, баби, нянь, репетиторів тощо), передачі дитини на виховання обсяг виховного впливу та контроль батьків щодо дитини зменшується. За таких обставин зменшення особистого контакту малолітньої особи з батьками та їх піклування зумовлені врахуванням інтересів дітей (розвиток здібностей, які вимагають залучення спеціалістів, влаштування до інтернату для дітей 3 особливими потребами) i батьків одночасно (необхідність працевлаштування для обох із них, бажання розвитку здібностей i навчання дитини).
Якщо при реалізації права на визначення форм виховання наявні ознаки відсутності необхідної турботи та негативного впливу на малолітню особу, особливо, якщо неучасть батьків у піклуванні та вихованні $€$ небезпечною для життя, здоров'я та морального виховання дитини, відповідні дії чи бездіяльність виходять за встановлені законом межі і набувають ознак зловживання правом.

Складний механізм реалізації має право дитини на врахування думки, особливо дитини дошкільного чи молодшого шкільного віку. Дитина має право на те, щоб бути вислуханою батьками, іншими членами сім’і 3 питань, що стосуються іï особисто, питань сім’і (ч. 1 ст. 171 СК Украіни) й виховання. Врахування думки дитини щодо цих питань і підстави обмеження його здійснення повинні бути дійсно виправданими найкращими їі інтересами. Викладене також пов'язано 3 підставами реалізації та обмеження здійснення спеціальної правомочності малолітньої особи чинити опір неналежному вихованню. Відповідні дії вчиняються без звернення до органів держаної влади, вони $є$ способом самозахисту.

Не може бути гарантій того, що до малолітньої особи батьки прислухаються, не розцінять опір як неповагу до себе, неслухняність, що викличе розвиток сімейного конфлікту. Тому слід відрізняти непідкорення дитини батьківський владі, яка знаходиться поза правовим регулюванням, та опір неналежному вихованню як спосіб самозахисту дитини, коли відповідна влада переходить встановлену законом межу.

Можна наводити чимало випадків, коли батьки недоречно обмежують задоволення найкращих інтересів дитини, що опосередковуються вихованням. Тому має бути гарантований механізм їх охорони та захисту власне від батьків, які недобросовісно здійснюють свої батьківські права та неналежно виконують покладені на них обов'язки [2, с. 116]. 
Є підстави стверджувати, що авторитарний i ліберальний стилі виховання за певних умов можна визнавати неналежним вихованням [17; 2, с. 303]. Ліберальний стиль має низку виявів ухилення від виховання, при авторитарному вихованні можна вести мову про невиконання батьками обов'язку здійснення належного виховання, що породжує право дитини чинити опір, адже батькам забороняється вчиняти будь-які види експлуатації своєї дитини, фізичні покарання та застосування інших видів впливу на дитину, що принижують іiі гідність і входять до арсеналу методів авторитарного стилю [18, с. 174]. Опір неналежному вихованню безпосередньо пов'язаний із правом малолітньої особи бути вислуханою та на врахування іï думки при вирішенні відповідних питань органами державної влади, що не мають недоречно обмежуватися із посиланням на вікові психічні особливості.

Таким чином, виховання дитини $€$ процесом, під час якого кожен із батьків виявляє свої педагогічні та психологічні знання та навички, враховуючи особливості власної морально-правової свідомості. Батьківське виховання має відповідні особливості для кожної сім’ї. Найкращі інтереси дитини є загальним критерієм встановлення і меж здійснення батьківських прав, оцінки виконання батьками обов'язків 3 виховання і обмежень здійснення права малолітньої особи на виховання. Їх збалансоване співвідношення разом 3 інтересами та правами батьків визначає правову природу та сутність обмежень здійснення зазначеного права. Тому на «систему державного контролю», проголошену у ст. 152 СК України, покладаються позитивні зобов'язання у забезпеченні прав малолітніх осіб.

3 метою недопущення непропорційного втручання у батьківські права, права на повагу до сімейного життя держава не може встановлювати імперативні способи їх здійс- нення, передбачає ті правові обмеження, які $€$ необхідними, зокрема, для захисту здоров'я чи моралі, захисту прав і свобод дітей. Обмеження здійснення права на належне батьківське виховання малолітніх осіб відображаються у правовому регулюванні шляхом встановлення умов реалізації окремих правомочностей, що складають зміст цього права та залежать від здійснення їх інших прав.

Вільна реалізація свого права батьками на визначення місця проживання та свободу пересування, права на повагу до сімейного, особистого життя, визначення форм і методів виховання зумовлюють пропорційне обмеження права дитини на виховання, що виявляється в обмеженні безперешкодного спілкування з обома батьками при роздільному проживанні з одним із них, обмеженні позитивного виховного впливу тощо.

Обмеження здійснення права бути вислуханою батьками та врахування думки дитини щодо питань виховання зумовлено віковими та психічними обмеженнями щодо усвідомлення обставин здійснення виховного впливу та своїх інтересів, так само як і опір неналежному вихованню обмежується найкращими інтересами, які дитина усвідомлює ситуативно.

Стаття присвячена актуальній проблемі обмежень здійснення права на належне батьківське виховання малолітніх осіб. Такі обмеження зумовлені природними факторами: нездатністю чи складністю для дитини задовольнити більшість своїх потреб, адекватно усвідомлювати їх значення. Оціночний характер належності виховання зумовлений складністю визначення меж правомірної поведінки батьків відносно виховання. Обмеження здійснення цьоого права визначаються іншими правами дитини та правами батьків, які створюють відповідні умови або перешкоди, визначають виникнення чи здійснення 
його окремої правомочності, полягають у забороні автономного вчинення дій особою до 14 років.

Доводиться, що задоволення інтересів дитини є можливим шляхом комплексного забезпечення ї прав батьками, щзо й здійснюються ними. Здійснення права на належне виховання не обмежується лише можливостями отримання виховання через спеціальні педагогічні, психологічні прийоми, що зумовлюе й інші обставини, які створюються при здійснені інших прав дитини або батьківських прав.

Проаналізовано право виїзу дитини за кордон, яке має розцінюватися крізь призму найкращих інтересів дитини, а не рівності прав батьків, зважаючи на можливість зловживання ними правом на надання дозволу. При встановленні роздільного проживання дитини з одним із батьків встановлюється передбачене законом обмеження здійснення права на наленне виховання. Запропоновано надати право дитині з десяти років ініціювати питання про своє місце проживання, якщо існуе спір між батьками.

Чинне законодавство не забороняе авторитарний $i$ ліберальний стилі виховання, що зумовлюе широкі межі батьківських прав у иій галузі $і$ відповідае міжнародним стандартам, надае право дитині в якості самозахисту протидіяти неналежному вихованню, шо відрізняється від непідкорення дитини батьківський владі.

Зроблено висновок, щзо методи виховання можуть бути важливим критерієм для визначення місия проживання дитини, визначення способів участі у вихованні того з батьків, хто проживає окремо, а іх зміна - при поверненні дитини батькам, поновленні батьківських прав, затвердженні плану соціального супроводу сім' $і$ дитини тощо.

Ключові слова: обмеження здійснення права на належне батьківське виховання, інтереси дитини, зловживання батьківськими правами, належні форми та методи виховання.

Makovetska V. Limitations on exercising the right for proper parental nurturing of children under the age of fourteen: defining the essence and the criterias

The article deals with the topical issue of limitations on exercising the right for proper parental nurturing of children under the age of 14. Such limitations are determined by natural factors: child's inability to satisfy most of his or her needs, to adequately recognize their significance and conditions of satisfying them. The evaluative character of the propriety of nurturing is determined by the difficulty of defining the limits of parents' lawful behavior concerning nurturing. Limitations on this right are influenced by the realization of other child's and parent's rights that create conditions or obstacles for its realization, determine the emergence or realization of its particular authority and lie in the fact that personally performing acts acting by a person under the age of 14 is prohibited or the realization of rights is delegated to the parents.

It is proved that satisfaction of a child's interests is possible in case of overall securing of his or her rights by the parents who have the respective responsibilities. Realization of the right is not limited to just a possibility of getting the nurturing through special methods and techniques, which makes it necessary to take into account other circumstances that arise during exercising other rights of a child or parents.

A child's right for going abroad is analysed. It must be assessed in terms of child's best interests rather than the equality of parental rights as there is a possibility of parents' abusing the right for giving permission. In case of establishing separate residence of 
a child less than 14 years with one of the parents there is a lawfully established limitation on exercising the right for proper nurturing. It is suggested that a child should be given the right to open an issue of his or her residence from the age of nine if there is a dispute between the parents.

Current legislation carries a risk of improper nurturing through authoritative and liberal styles, which is determined by the wide limits of parental rights concerning nurturing but at the same time conforms with international standards. Opposition to improper nurturing, which is an attempt of self-defence, is different from child's disobedience to parental authority.

A conclusion is drawn that nurturing methods can be an important criterion for establishing a child's place of residence and the ways of how the parent who lives separately participates in the nurturing, while changes in nurturing methods can be a criterion for returning the child to the parents, for restoration of parental rights, for confirming the plan of social support of a child's family etc.

Key words: limitations on exercising the right for proper parental nurturing, the interests of the child, abuse of parental rights, proper forms and methods of upbringing.

\section{Література}

1. Стефанчук М.О. Межі здійснення суб'єктивних ичивільних прав : дис. канд. юрид. наук: 12.00.03. НАН України, Інститут держави і права ім. В.М. Корецького. K., 2006. 201.

2. Синєгубов О.В. Здійснення особистих немайнових прав осіб, які не досягли повноліття : дис. докт. юрид. наук: 12.00.03. Харків, 2015. 508 c.

3. Мічурін Є.О. Межі та обмеження цивільних прав. Право $і$ безпека. 2010. № 3. C. 212-215. URL: http: / / nbuv.gov.ua/ UJRN / Pib_2010_3_47.

4. Постановление Судебной палаты по гражданским делам Вер- ховного Суда Украинь от 12.04.2017, дело № 235/139/16-u. URL: http:// search.ligazakon.ua/l_doc2.nsf/link1/ VS170197.html.

5. Кожевнікова В.О. Науково-теоретичні засади обмеження прав суб'єктів сімейних відносин : дис. докт. юрид. наук: 12.00.03. НДІППіП імені академіка Ф.Г. Бурчака, НАПН України, ТНЕУ, мОН України. Тернопіль, 520 с.

6. Красицкая Л.В. Проблеми здійснення та захисту особистих та майнових прав дітей $i$ батьків: дис. докт. юрид. наук: 12.00.03. ДНУ. Вінниця, 2015. $496 \mathrm{c}$.

7. Труба В.І. Право дитини на виїзд за межі України. Актуальні проблеми науки i практики циивільного, житлового та сімейного права: матеріали Міжнарод. наук.-практ. конф., присвяч. 91-річчю з дня народження В.П. Маслова, (Харків, 15 лютого 2013 року). Х. : Право, 2013. C. 50-52.

8. Рішення Петрівського районного суду Кіровоградської області від 09.03.2017, справа № 400/1621/16-u. ЭДРCP. URL: http://reyestr.court.gov.ua/ Review/65308806.

9. Постанова Великої палати Верховного суду від 04.07.2018, справа № $712 / 10623 / 17$. ЭДРСP. URL: http:// www.reyestr.court.gov.ua/Review/ 75266002 .

10. Про виховання та освіту дітей від народження до 8-річного віку: Коміmет Міністрів Ради Європи, рекомендація № $R(81) 3$ від 23.01.1981. URL: https: / / zakon.rada.gov.ua / laws / show/994_730\#Text.

11. О политике в поддержку позитивного воспитания детей родителями: Комитет Министров Совета Европь, рекомендация № $R(2006) 19$ om 13.12.2006. URL: https: / / www.refworld.org.ru/docid/ 5514017f4.html.

12. Пунда О.О. Право на сімейне виховання та проблеми його здійснення. Вісник Запорізького нациіонального університету. Юридичні науки. 2005. № 1. C. 111-115.

13. Бойчук П.М., Борбич Н.В Виховні можливості батьківського авторитету. Молодий вчений. 2018. № 21.1. С. 17-20. URL: http:// molodyvcheny.in.ua/files/ journal/2018/12.1/5.pdf (dama звернення: 23.06.2020)

14. The APSAC Handbook on Child Maltreatment / ed. by John E.B. Myers. 


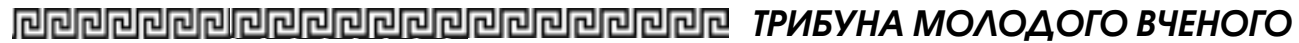

Third Edition. University of the Pacific, 2011. $464 p$.

15. Игошев К.Е., Миньковский Г.М. Семья, дети, икола. М. : Юрид. лит. 1989. 448 c.

16. Мироненко В.П. Межі здійснення батьківських прав. Юридична наука. 2012. № 5. C. 59-65. URL: http:// nbuv.gov.ua/UJRN/jnn_2012_5_7.

17. Трофаїла Н.Д. Емоційний розвиток дітей дошкільного віку. Науковий вісник МДУ імені В.О. Сухомлинського. Педаго- гічні науки. 2014. Bun. 1.45. C. 155-158. URL: http: / / nbuv.gov.ua/UJRN/Nvmdup_ 2014_1.

18. Синєгубов О.В. Тлумачення права на належне батьківське виховання в контексті його здійснення неповнолітньою особою. Науковий вісник Ужгородського національного університету. Серія «Право». 2014. Bun. 27(1). C. 172-175. URL: http: / / nbuv.gov.ua/UJRN/nvuzhpr_ 2014_27(1)_45. 